\title{
Anaerobic biodegradation of cassava wastewater under different temperatures and inoculums
}

\author{
Miriam Cleide Cavalcante de Amorim*, Paula Tereza de Souza Silva², \\ Patricia Silva Barbosa', Nayara Evelyn Montefusco'
}

\footnotetext{
'Federal University of the São Franscisco Valley, Petrolina, Brazil

2Brazilian Agricultural Research Corporation, Petrolina, Brazil

*Corresponding author, e-mail: miriam.cleide@univasf.edu.br
}

\begin{abstract}
The production of starch generates, as a by-product, the cassava wastewater (manipueira), which can be treated by anaerobic digestion to provide biogas and minimize its polluting potential. The most commonly utilized biomass in the anaerobic digestion is the anaerobic sludge. The literature presents, as an alternative to sludge, bovine manure and ruminal fluids, being scarce the studies with the cassava wastewater. This research evaluated the influence of temperature on the microbial ability of cattle and goat rumen in anaerobically biodegrading the manipueira in substitution to the anaerobic sludge. The cattle and goat rumen specific methanogenic activities (SMA) were compared with that of the anaerobic sludge. Subsequently, by using the inoculum which had the best SMA results, cassava wastewater biodegradability tests were performed, investigating the kinetics of the organic matter removal and methane production at $32^{\circ} \mathrm{C}$ and $39^{\circ} \mathrm{C}$. The bovine rumen presented better results in the SMA $(0,315$ $\mathrm{g}$ COD-CH $\mathrm{g} \mathrm{VSS}_{4} \mathrm{~d}^{-1}$ ) and methane production $(1,026 \mathrm{~mL})$. The temperature of $32{ }^{\circ} \mathrm{C}$ did not influence the activity of bovine ruminal inoculum as the kinetics of the biodegradation of the manipueira did not differ for the evaluated temperatures $\left(0.1799 \mathrm{~d}^{-1}\right.$ at $32^{\circ} \mathrm{C}$ and $0.1781 \mathrm{~d}^{-1}$ at $39^{\circ} \mathrm{C}$ ). Bovine rumen achieved glucose reduction of $76 \%$ and $80 \%$ and methane yield of $77 \%$ and $79 \%$ for the tests at $32^{\circ} \mathrm{C}$ and $39^{\circ} \mathrm{C}$, respectively. It is inferred that this type of inoculum might be used in reactors of anaerobic digestion processes for the treatment of the cassava wastewater at the ambient temperature of the semiarid region.
\end{abstract}

Keywords: Biodegradability, methane, rumen, cassava wastewater

Introduction
The cultivation of cassava and the

farming of goats and cattle are economic and subsistence activities in the Brazilian semiarid region. Brazil and Indonesia are the largest producers of cassava for consumption and production of flour and starch, whose main byproduct is the manipueira (cassava wastewater), besides shavings and leaves (Ubalua 2007; Zhang et al., 2016), which, treated through anaerobic microbial digestion, generate the biogas that might be used as a source of renewable energy (Kuczman et al., 2014), minimizing its polluting potential (Okudoh et al., 2014; Sanches et al., 2017).
Anaerobic digestion requires an interaction of fermentative and methanogenic microorganisms (microbial biomass), being particularly dependent on a strict control of environmental conditions (temperature, $\mathrm{pH}$, alkalinity) (Chernicharo, 2007).

The most commonly used biomass in the processes of anaerobic digestion is the anaerobic sludge of digesters in sewage treatment plants or agroindustries, in concentrations from 2 to 5 $g$ of volatile suspended solids (VSS).L-1 (Anyanwu et al. 2015). Considering that there are places where there are no anaerobic treatments which can provide such inoculums, literature presents as an alternative to anaerobic sludge: cattle 
manure (Sen and Suttar, 2012), swine manure (Panichnumsin et al., 2012), chicken manure (Luo et al., 2010), microalgae (Budiyono and Kusworo, 2011) and stomach fluids of ruminants (Ward et al., 2008; Budiyono et al., 2009) with comparison studies within inoculums (Elbeshabishy et al., 2010; Astals et al., 2013), being scarce the studies with cassava wastewater.

The specific methanogenic activity (SMA) measures the maximum rate of methane production under specific conditions, evaluating the biomass ability to convert an organic substrate into methane (Souto et al., 2010). Consequently, this biomass must possess a high SMA in order to contribute to the success of anaerobic digestion.

The literature indicates that most of the anaerobic reactors are projected in the mesophilic range (Kaparaju et al., 2010; Sun et al., 2012; Intanoo et al., 2016), being the predominant methane-forming microorganisms, in anaerobic reactors operated in the range of $30-35^{\circ} \mathrm{C}$, those of the genera Methanobacterium, Methanobrevibacter (hydrogenotrophs) and Methanospirillum, and the genera Methanosarcina and Methanosaeta (acetoclastic) (Tchobanoglous et al., 2003; Gerardi, 2006). However, observing the ideal environmental conditions for the bacteria of the ruminal ecosystem, the optimum temperature is $39^{\circ} \mathrm{C}$ (Hook et al., 2010).

In this sense, this research evaluated the influence of temperature on goat and cattle microbial ruminal ability in aerobically biodegrading the cassava wastewater in replacement to the anaerobic sludge. In order to perform it, were compared the specific methanogenic activities (SMA) of the rumens and of an anaerobic sludge, the reduction efficiency of organic matter and the methane production thorough the removal kinetics of each inoculum.

\section{Material and methods:}

\section{Substrate and inoculums}

The cassava wastewater came from a flour house in the city of Araripina, Pernambuco state, Brazil. The goat and cattle ruminal fluids utilized as inoculums were directly collected from the pre-stomach of the animals and filtered through cotton cloth. The anaerobic sludge was collected from an upflow anaerobic sludge blanket (UASB) reactor utilized in the treatment of domestic sewage in the city of Recife, PE. Table 1 shows the characteristics of the cassava

Table1. Characteristics of the cassava wastewater and ruminal fluids

\begin{tabular}{|c|c|c|c|c|}
\hline Parameters & $\begin{array}{c}\text { Cassava } \\
\text { wastewater }\end{array}$ & $\begin{array}{l}\text { Bovine } \\
\text { rumen }\end{array}$ & $\begin{array}{c}\text { Goat } \\
\text { rumen }\end{array}$ & $\begin{array}{l}\text { Anaerobic } \\
\text { sludge }\end{array}$ \\
\hline COD (mg. $\left.\mathrm{L}^{-1}\right)$ & 37700 & 3774 & 4316 & 420 \\
\hline $\mathrm{pH}$ & 5,80 & 7,5 & 7,21 & 7,03 \\
\hline Total phosphorus (mg. $\mathrm{L}^{-1}$ ) & 183 & 5733 & 4123 & 5,01 \\
\hline Ammoniacal nitrogen (mg. $\left.\mathrm{L}^{-1}\right)$ & 28 & 174 & 162 & 120 \\
\hline Alkalinity (mg CaCO${ }_{3} \mathrm{~L}^{-1}$ ) & 72 & 5733 & 4283 & 460 \\
\hline Volatile acids (mg HAC. $L^{-1}$ ) & 25 & 9883 & 8824 & 3540 \\
\hline Volatile suspended solids (mg VSS.L-1) & 4332 & 16000 & 9400 & 37710 \\
\hline
\end{tabular}

wastewater and of the three inoculums.

Specific methanogenic activity (SMA)

For the SMA essays, the methodologies of Field et al. (1988) and Florêncio et al. (1993) were adopted, utilizing as substrate a mixture of acetic, propionic and butyric acids in a concentration of

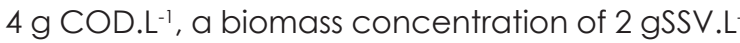
'of the inoculum and manual agitation every 12 hours in all incubated bottles, according to Souto et al. (2010), with an average duration of 30 days.

For each essay, 1.3 L reactor bottles were used in triplicates, with a headspace volume of
$20 \%$ (Aquino et al., 2007) and sealed with rubber septa, connected to a $15 \mathrm{~mL}$ surgical syringe through a glass hose to transport the biogas. The reactor bottles, along with control bottles, inoculated without the introduction of the substrate, were incubated in a room maintained at $32 \pm 2^{\circ} \mathrm{C}$ through a $1500-\mathrm{W}$ ambient heater, and manually and intermittently shaken (Souto et al., 2010) every 12 hours.

The biogas measurement was performed through the volumetric method of direct measurement of methane volume by washing 
the biogas from the reactor bottle through the glass hose in a solution of $3,0 \%(\mathrm{~m} / \mathrm{v})$ sodium hydroxide for absorption of $\mathrm{CO} 2$ (Aquino et al., 2007). The produced methane volume was gauged by measuring the volume of the sodium hydroxide solution displaced by the washed gas (Aquino et al., 2007).

The value of the maximum specific methanogenic activity of each inoculum (g $\left.\mathrm{COD}_{\mathrm{CH} 4} / \mathrm{gVSS} . \mathrm{d}\right)$ was calculated from the maximum methane productions in 24 hours, according to Equation 1:

$$
S M A=\frac{V_{C H_{4}} / t}{f . V S S . V_{u}}
$$

Where is the maximum methane volume produced in the considered time interval $(\mathrm{mL}) ; t$ is the considered time interval (days); $f$ is the stoichiometric conversion factor (the Temperature of $30^{\circ} \mathrm{C} 1 \mathrm{~g}$ DQO is equivalent to $390 \mathrm{ml}$ of $\mathrm{CH} 4$ produced); VSS is the biomass concentration $(\mathrm{g} / \mathrm{L}) ; V_{u}$ is the useful volume of the flask.

Effect of incubation temperature on ruminal microbial activity

In order to evaluate the effect of incubation temperature on ruminal microbial activity in the biodegradability of the cassava wastewater, only the ruminal content which presented best SMA performance was used as inoculum. The essays were conducted in 0,130 L reactor bottles, utilizing $0,104 \mathrm{~L}$ of usable volume at $0,026 \mathrm{~L}$ headspace. The ruminal biomass concentration was $2 \mathrm{~g} \mathrm{VSSL}^{-1}$. The temperatures of 32 and $39 \pm 2{ }^{\circ} \mathrm{C}$, were tested in a $Q 316 \mathrm{M}$ model incubator, thus characterizing two treatments (Table 2).

able 2. Experimental configurations for biodegradation evaluation

\begin{tabular}{ccccc}
\hline Treatments & $\begin{array}{c}\text { Inoculum biomass } \\
\left(\mathrm{g} \vee S S . \mathrm{L}^{-1}\right)\end{array}$ & Inoculums & $\begin{array}{c}\text { Substrate } \\
\left(2 \mathrm{~g} \mathrm{DQ} \mathrm{O} . \mathrm{L}^{-1}\right)\end{array}$ & $\begin{array}{c}\text { Temperature } \\
\left({ }^{\circ} \mathrm{C}\right)\end{array}$ \\
\hline 1 & 2 & Bovine rumen & Cassava wastewater & 32 \\
2 & 2 & Bovine rumen & Cassava wastewater & 39 \\
\hline
\end{tabular}

The cassava wastewater was added to the reactor bottles in the concentration of $2 \mathrm{~g}$ COD. $L^{-1} 24$ hours after the addition of the inoculum and nutrients, in order to provide adaptation of the microorganisms to the environment. The concentrations of macro $\left(\mathrm{N}_{-} \mathrm{NH}_{4}^{+}, \mathrm{P}_{-} \mathrm{PO}_{4}^{+}, \mathrm{Mg}\right.$, $\mathrm{Ca}$ ) and micro nutrients (Fe, Ni, Zn, Co...), besides alkalinity $\left(\mathrm{NaHCO}_{3}\right)$, were maintained in each reactor bottle (per liter) considering the nutritional requirements of the sludge microorganisms recommended by Florêncio et al.(1993) and the rumen microorganisms, as recommended by $\mathrm{Hu}$ et al. (2007) and Baba et al., 2013).

On day 0 all triplicates were prepared at the same time, sealing the reactor bottles with rubber septa and aluminum seals, and adapting $15 \mathrm{ml}$ to the septa for the collection and measurement of the generated methane gas. Three sets were prepared for analysis on days $0,1,3,5,7,9$ and 11. The method followed the methodology of Amorim et al. (2013), which consists in removing a triplicate set at every established time interval for sampling and analysis of the reaction content. Every 48 hours a triplicate set had its reaction content analyzed separately, and after the sampling the three reactor bottles were discarded. Control bottles were prepared, although without substrate addition. The maximum digestion time of 264 hours ( 11 days) was adopted.

The methane measurement was daily, and performed through the volumetric method of Direct Measurement of Methane Volume, by washing the biogas from the reactor bottle through a glass hose in a solution of $3.0 \%$ caustic soda to absorb $\mathrm{CO}_{2}$ (Aquino et al., 2007).

The agitation was manual (Souto et al., 2010) in all incubated bottles.

The following parameters were analyzed: $\mathrm{pH}$, total and filtered COD in 0,45 $\mu \mathrm{m}$ membrane, partial alkalinity (PA) and volatile fatty acids (VFA) in mg Acetic acid. $\mathrm{L}^{-1}$. The anaerobic biodegradability of the cassava wastewater, under different temperatures, was evaluated through the following parameters: filtered COD removal efficiency (COD), Total Solids (TS), Total Volatile Solids (TVS), Volatile Suspended Solids of 
the biomass (VSS) and glucose (APHA, 2012). The methane rate of production or yield $\left(\mathrm{T}_{C H 4}\right)$ was determined through the relation between the volume of effectively produced and measured methane and the applied COD mass of the system ( $\mathrm{mL} \mathrm{CH}_{4} \cdot \mathrm{g}^{-1} \mathrm{COD}_{\text {applied }}$ ), and the methane yield in relation to the theoretical methane

$\left(R_{C H 4}\right)$.

According to Bertolino et al. (2008), the knowledge of the substrate utilization kinetics is an important parameter for the verification of the microorganisms' ability in stabilizing the organic matter present in the sewage, that is, to determine the treatability of the effluent. In order to evaluate the rate of organic matter consumption during the biodegradability tests in the reactor bottles, the $\mathrm{K}$ constant was determined through Equation (2). Teixeira et al.(2008), obtained that the firstorder kinetics was the one which best fit the obtained results for COD removal.

$$
(-r)=-\frac{d S}{d t}=k_{d} S
$$

Where: $r$ is the reaction rate (mass/ volume. time), $S$ is the concentration of the limiting reactant (mass/volume), $T$ is the time (days) and $K_{d}$ is the rate constant for first-order reaction $\left(\right.$ day $\left.^{-1}\right)$.

The results were statistically evaluated in the ASSISTAT $^{\circledR}$ software (Beta Version 7.7), through descriptive statistics and Analysis of Variance (ANOVA) applying the Shapiro-Wilk homoscedasticity test. Confirmed a significant difference ( $p$-value $<0,05$ ) to compare the means, a significance level of $5 \%$ was adopted. Tukey's test was applied for the parametric data series, and Kruskal-Wallis test for non-parametric data, which compares three or more independent samples, indicating if there is a difference within at least two of them.

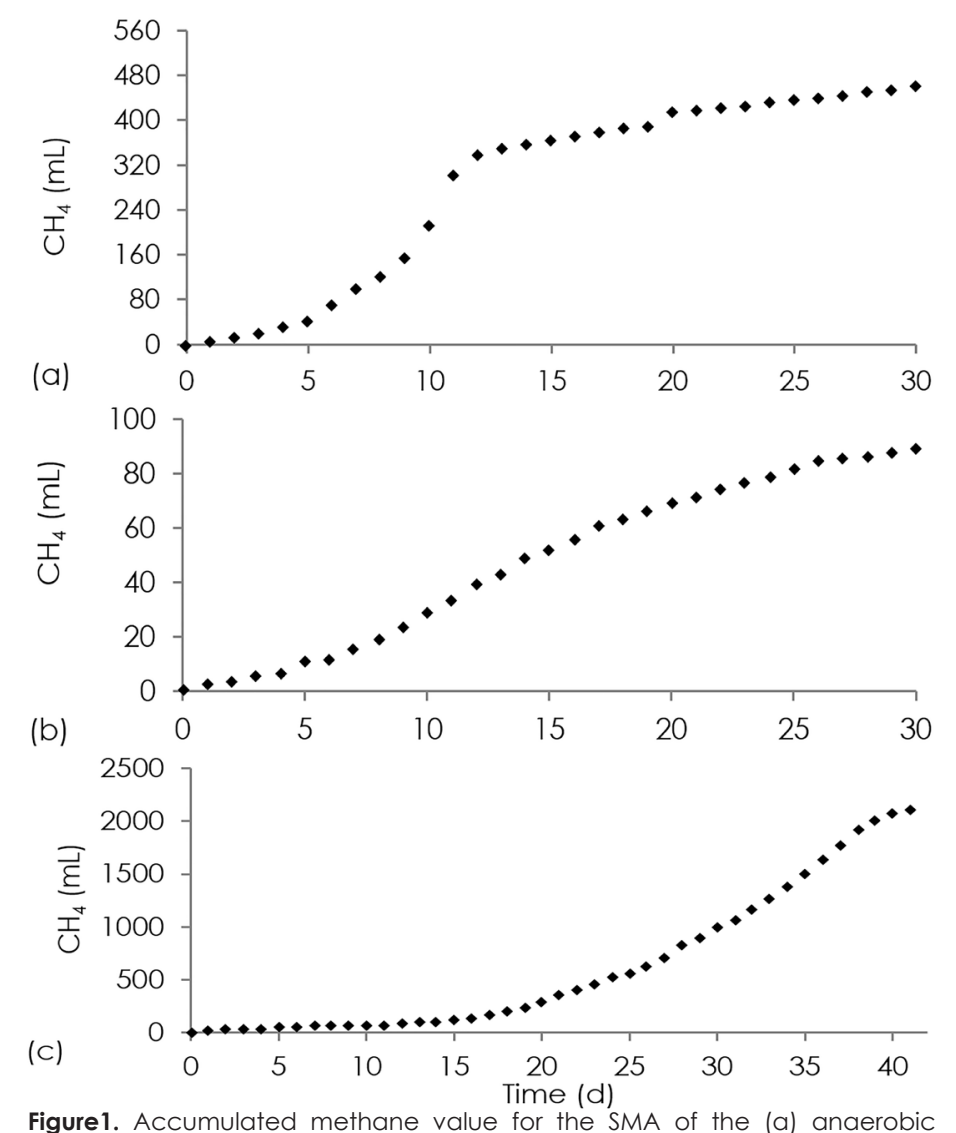

Figure1. Accumulated methane value for the SMA of the (a) anaerobic sludge, (b) goat rumen and (c) bovine rumen

\section{Results and discussion:}

Specific Methanogenic Activity

The cumulative productions of methane in the SMA essays were highly varied, as might be observed in Figures $1 \mathrm{a}, 1 \mathrm{~b}$ and $1 \mathrm{c}$, as well as the accumulated methane production in terms of $\mathrm{g}$ $\mathrm{COD}_{\mathrm{CH} 4} / \mathrm{d}$ (Figure 2). Whilst for the anaerobic sludge (Figure $1^{a}$ ) 
there was a production of circa $350 \mathrm{~mL}$ until the $15^{\circ}$ day, in the same period the production was of $50 \mathrm{~mL}$ for the goat rumen (Figure $1 \mathrm{~b}$ ) and of 150 $\mathrm{mL}$ for the bovine rumen (Figure 1c). However, at the end of the $30^{\circ}$ day, the highest methane production was for the SMA of the bovine rumen with $1.026 \mathrm{~mL}$ of methane, followed by the SMA of the anaerobic sludge with $460 \mathrm{~mL}$ and by the goat rumen with $91 \mathrm{~mL}$. It was observed that either for the cumulative methane production (Figures
$1 \mathrm{a}, 1 \mathrm{~b}$ and $1 \mathrm{c}$ ) as for the COD loads converted into methane (Figure 2), the bovine rumen, even after the 30 days, did not present a tendency for the stabilization of methane production. As for sludge and goat rumen, from the twelfth day, there was a tendency for stabilization. The volumes are only related to the conversion of the substrate into methane, since that in the control serum bottles there was no methane production.

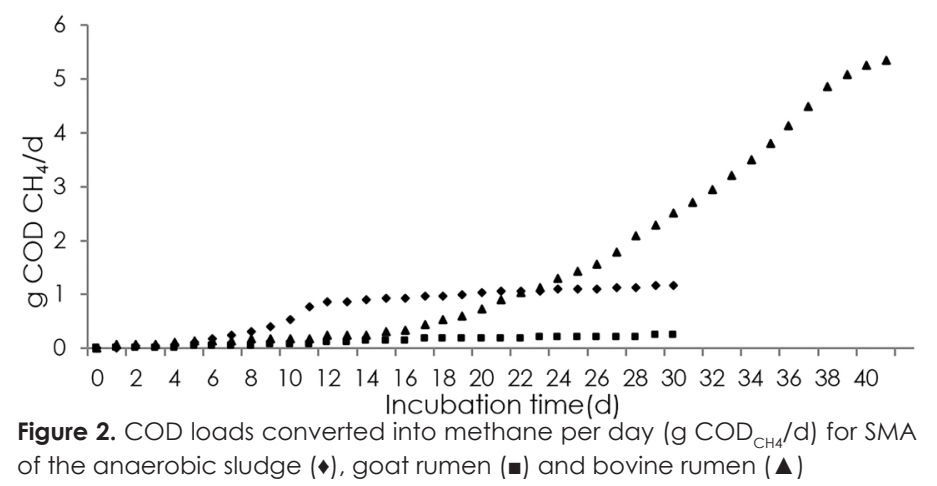

The maximum rates of methane Table 3 presents the SMA values for the production for the anaerobic sludge and for goat rumen occurred between the seventh and the ninth day of the test. As for the bovine rumen, they occurred between the twenty-third and twenty-fifth days. hree inoculums in the stretch of highest activity, expressed in accumulated volume of methane $\left(\mathrm{mLCH}_{4} / \mathrm{d}\right)$ and as mass of COD converted into methane ( $\mathrm{g} \mathrm{COD}_{\mathrm{CH} 4} / \mathrm{d}$ ) per quantity of biomass in $g$ VSS.

Table 3. Obtained SMA of the three evaluated inoculums

\begin{tabular}{|c|c|c|}
\hline Inoculums & \multicolumn{2}{|c|}{ SMA } \\
\hline Anaerobic sludge & $48 \mathrm{~mL} \mathrm{CH}_{4} / \mathrm{gVSS} . \mathrm{d}$ & $0,210 \mathrm{~g} \mathrm{COD}_{\mathrm{CH}_{4}} \mathrm{~g}^{-1} \mathrm{VSS} . \mathrm{d}^{-1}$ \\
\hline Goat rumen & $16 \mathrm{~mL} \mathrm{CH} / \mathrm{gVSS} . \mathrm{d}$ & $0,014 \mathrm{~g} \mathrm{COD} \mathrm{CH}_{4} \mathrm{~g}^{-1} \mathrm{VSS} \cdot \mathrm{d}^{-1}$ \\
\hline Bovine rumen & $113 \mathrm{~mL} \mathrm{CH} / \mathrm{gVSS} . \mathrm{d}$ & $0,315 \mathrm{~g} \mathrm{COD}_{\mathrm{CH} 4} \mathrm{~g}^{-1} \mathrm{VSS} \cdot \mathrm{d}^{-1}$ \\
\hline
\end{tabular}

Although for the anaerobic sludge and for the goat rumen the maximum rates of methane production have occurred in the same period, the SMA value for the goat rumen was quite inferior to that of the anaerobic sludge, with this same value being found by Lucena et al. (2001) for this type of sludge, as well as by Sun et al. (2012) who, characterizing the SMA of the anaerobic sludge treated with cassava wastewater, obtained values of 0,31 and 0,73 gCOD $\mathrm{CH}_{4} / \mathrm{g}$ VSS.d, corresponding to 134,23 and $316,09 \mathrm{~mL} \mathrm{CH} /$ (g VSS.d). The SMA of the bovine rumen presented the highest value, but a longer test time was necessary. The SMA values, either for the anaerobic sludge as for the bovine rumen, were superior to the values of 0,10 and $0,17 \mathrm{~g}$
$\mathrm{COD}_{\mathrm{CH} 4} \mathrm{~g}^{-1}$. VSS $\mathrm{d}^{-1}$ for the food sludge, found by Schneiders et al. (2013).

Considering that the influence of the VSS concentration on biomass and the concentration of substrate, described by Souto et al. (2010) were eliminated, since the same concentration of VSS was utilized for all inoculums and the same concentration of substrate in the three SMA, the differences within the SMA values might be attributed to the different types of microbial mass.

The SMA of the goat ruminal inoculum might have been inhibited by the temperature in which the test was performed $\left(32 \pm 2^{\circ} \mathrm{C}\right)$, seen that, according with Hook et al. (2010), the optimal temperature for the ruminal microorganisms is $39^{\circ} \mathrm{C}$. It is also a fact which justifies an adaptation 
of the cattle ruminal microorganisms at the temperature of $32^{\circ} \mathrm{C}$, that after the $25^{\circ}$ test day the methane production was increased, tending to stabilize around the $38^{\circ}$ day.

Effect of the incubation temperature on the bovine ruminal microbial activity during the biodigestion of cassava wastewater

Behavior of the Environmental Parameters

The normality test indicated an abnormal distribution for the $\mathrm{pH}$ data ( $\mathrm{p}$-value 0,00875 ) and normality of the data of PA (p-valor 0,70347$)$ and VFAs ( $p$-value 0,23117, with average values and standard deviations presented in Table 4.
Tukey's test with $5 \%$ of significance level identified that the $\mathrm{pH}$ values in the effluent are statistically different, that is, the temperature did influence in the $\mathrm{pH}$ value. The affluent $\mathrm{pH}$ values were close to 6,80 . The $\mathrm{pH}$ of the effluents were close to neutrality at $32^{\circ} \mathrm{C}$ and presented alkaline character $(8,00)$ in case of the biomass at $39^{\circ} \mathrm{C}$.

Tukey's test with $5 \%$ of significance level identified that the PA and VFAs values in the effluent are statistically equal, that is, the temperature did not influence in the results of the alkalinity and the VFAs during the biodegradation of the cassava wastewater with bovine rumen.

Table 4. Means and standard deviation of the $\mathrm{pH}$, PA and VFAs in the beginning and in the last day

\begin{tabular}{|c|c|c|c|c|}
\hline & \multicolumn{2}{|c|}{ Beginning } & \multicolumn{2}{|c|}{ Last day } \\
\hline & $32^{\circ} \mathrm{C}$ & $39^{\circ} \mathrm{C}$ & $32^{\circ} \mathrm{C}$ & $39^{\circ} \mathrm{C}$ \\
\hline $\mathrm{pH}$ & $6,75 \pm 0,08$ & $6,83 \pm 0,08$ & $7,00 \pm 0,00 \mathrm{~b}$ & $8,00 \pm 0,00 a$ \\
\hline $\mathrm{PA}\left(\mathrm{mgCaCO} \mathrm{L}_{3} \mathrm{~L}^{-1}\right)$ & $198,67 \pm 8,33$ & $225,00 \pm 44,19$ & $150,60 \pm 8,33 a$ & $141,33 \pm 5,66 a$ \\
\hline VFAs (mgHAc. $\left.L^{-1}\right)$ & $650,45 \pm 33,40$ & $650,39 \pm 5,11$ & $627,65 \pm 21,39 a$ & $626,23 \pm 3,17 a$ \\
\hline
\end{tabular}

Removal of biodegradable organic compounds

Table 5 presents the descriptive statistic of the results of the removal efficiencies (RE) during the biodegradability of cassava wastewater, of $\mathrm{COD}_{\mathrm{T}}$ and $\mathrm{COD}_{\mathrm{F}^{\prime}}$ of glucose, and the TS and TVS at $32^{\circ} \mathrm{C}$ and $39^{\circ} \mathrm{C}$.

The normality test indicated a normal distribution for the values of removal efficiency of the COD, COD $F^{\prime}$ carbohydrate, total solids of the liquid phase and total volatile solids ( $p$-value $0,33266)$. The statistic results of comparison within the removal efficiency means of $\mathrm{COD}_{T^{\prime}} \mathrm{COD}_{\mathrm{F}}$ and glucose were not significant. Nevertheless, by analyzing the data in Table 5, it might be verified that the comparison of the removal means of TS and TVS presented significant differences within each other, although not significant when compared for the temperatures of $32^{\circ} \mathrm{C}$ and $39^{\circ} \mathrm{C}$. In this manner the statistical analysis puts in evidence that the evaluated temperatures did not affect the activity of the ruminal inoculum during the biodegradation of the cassava wastewater.

Table 5. Descriptive statistic of the results at $32^{\circ} \mathrm{C}$ and $39^{\circ} \mathrm{C}$

\begin{tabular}{|c|c|c|c|c|c|c|c|c|c|c|}
\hline \multicolumn{6}{|c|}{ RE (\%) at $32^{\circ} \mathrm{C}$} & \multicolumn{5}{|c|}{$\mathrm{RE}(\%)$ at $39^{\circ} \mathrm{C}$} \\
\hline & $\mathrm{COD}_{\mathrm{T}}$ & $\mathrm{COD}_{\mathrm{F}}$ & Glucose & TS & TVS & $\mathrm{COD}_{\mathrm{T}}$ & $\mathrm{COD}_{\mathrm{F}}$ & Glucose & TS & TVS \\
\hline Mean & $74 a$ & $71,7 \mathrm{a}$ & $76,2 a$ & $33,3 b$ & $46 c$ & $73,2 a$ & $70,5 a$ & $75,7 a$ & $36 \mathrm{~b}$ & $41,3 c$ \\
\hline$S D$ & 1,582 & 3,185 & 2,320 & 5,068 & 1,330 & 1,124 & 4,109 & 3,882 & 6,940 & 2,89 \\
\hline CV (\%) & 2,14 & 4,44 & 3,04 & 15,23 & 2,90 & 1,54 & 5,8336 & 5,13 & 19,28 & 7,01 \\
\hline Var & 2,504 & 10,153 & 5,382 & 25,684 & 1,775 & 1,263 & 16,890 & 15,072 & 19,280 & 8,386 \\
\hline
\end{tabular}

Figures 3 and 4 demonstrate the removal efficiencies of the $\mathrm{COD}_{T}, \mathrm{COD}_{\mathrm{F}}$ and carbohydrates in terms of glucose. It was observed that at the end of the biodegradation period, the behavior of the $\mathrm{COD}_{T^{\prime}}, \mathrm{COD}_{\mathrm{F}}$ and glucose were similar, either at $32^{\circ} \mathrm{C}$ as at $39^{\circ} \mathrm{C}$, what did not occur with the TS of the liquid phase, which, although having been reduced, its percentage did not follow the 
cited parameters. This was also observed in Table 5 and Figure 5, whose TS reductions were of 33,3\% $\left(32^{\circ} \mathrm{C}\right)$ and $36 \%\left(39^{\circ} \mathrm{C}\right)$.

According with the data of Table 5, a decrease in the total volatile solids of the liquid phase was observed, as well as the increase in

$$
\begin{array}{ll}
\frac{5}{50} \\
\overline{0} \\
\frac{0}{0} \\
\frac{8}{0} \\
\frac{1}{0} \\
0 \\
0
\end{array}
$$$$
\begin{aligned}
& 80 \\
& 75 \\
& 70
\end{aligned}
$$$$
75
$$

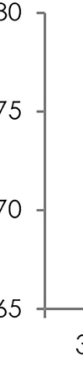

the concentration of the volatile suspended solids in the biomass, either for the biodegradation at $32^{\circ} \mathrm{C}$ as at $39^{\circ} \mathrm{C}$, what was expected, mainly because the essays were performed in batch reactor, in the absence of biomass drag, common in continuous flow systems.

Figure 3. Removal efficiency of the $C O D_{T}\left(D Q O_{T}\right)$ and $C O D_{F}\left(D Q O_{F}\right)$ at the end of the biodegradation period

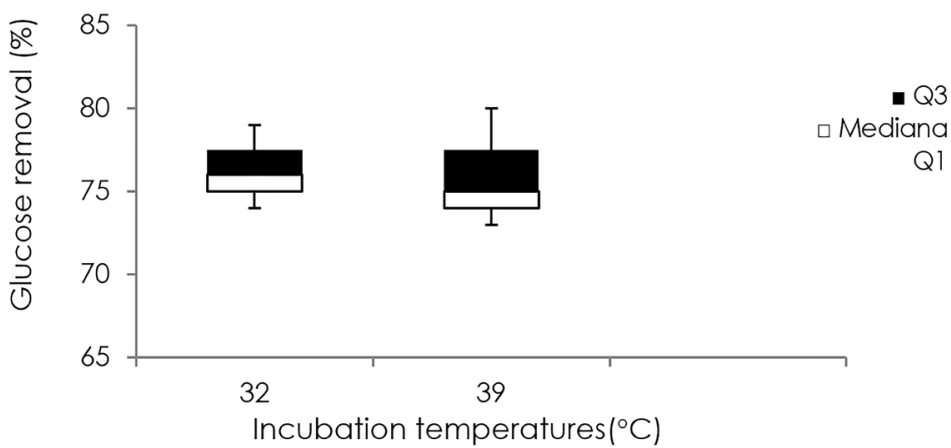

Figure 4.Removal efficiency of glucose after the biodegradation period

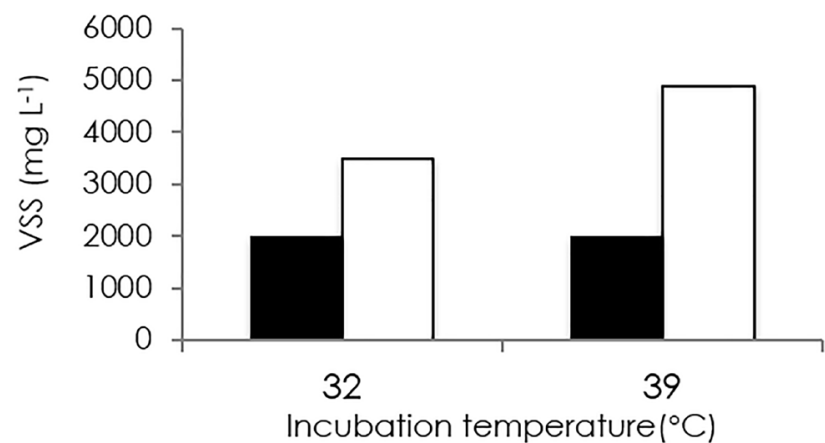

Figure 5. Volatile suspended solids of the biomass at the beginning ( $\mathbf{m})$ and at the end ( $\square$ )

By statistically comparing the reduction means of the TVS values of the liquid phase at $32^{\circ} \mathrm{C}$ and at $39^{\circ} \mathrm{C}$ there was no significance ( $p$-value 0,64756), with the same occurring for the increase in the VSS values of the biomass for both temperatures ( $\mathrm{p}$-value 0,87554). The temperature did not statistically affect the reduction of the TVS nor the increase in biomass, although, in absolute values, the highest increase percentage was observed for the biomass incubated at $39^{\circ} \mathrm{C}$, according with Figure 5.

In this manner it is worth noting that, statistically, there were no significant differences within the obtained results for the removal of organic matter of the effluent at different temperatures, inferring that it might be possible to utilize bovine rumen as inoculum in anaerobic biodegradation processes at the same temperature utilized for the sludge of anaerobic sewages, that is, at $32^{\circ} \mathrm{C}$. 
Coefficient of kinetic decay of the COD, $K_{i}\left(d^{-1}\right)$

The kinetic data of the biodegradation and the descriptive statistic are presented in Table 6 for COD and glucose, and, in Table 7, for the total solids and total volatile solids. The statistical evaluation indicated normality for the average values of the decay rate $\mathrm{K}_{\mathrm{i}}\left(\mathrm{d}^{-1}\right)$ constants for the COD and glucose (p-value 0,77034), and for TS and TVS (p-value 0,58527).

The means comparison through Tukey's test at the level of $5 \%$ probability of $\mathrm{K}_{i}$ for removal of COD and glucose presented $F$ value 1,6551, not being, therefore, significant $(p>=0,05)$. As for the
TS and TVS, the F value of the ANOVA was 4,8758, being significant at the level $5 \%$ probability, as might be verified in Table 7, highlighting that the difference was significant only within the $K_{i}$ values for the TS and TVS $32^{\circ} \mathrm{C}$. That is, the degradation rate of the TVS was higher than the degradation rate of the TS at the temperature of $32^{\circ} \mathrm{C}$, not being significant when compared the average $\mathrm{K}_{i}$ values with the temperature of $39^{\circ} \mathrm{C}$, indicating the potential of the microbial mass of the bovine rumen for the biodegradation of organic compounds, and that the temperature did not interfere in this ability of the inoculum.

Table 6. Coefficient of kinetic decay $\left(K_{i}\right)$ for COD and glucose

\begin{tabular}{ccccccc}
\hline & \multicolumn{3}{c}{$\mathrm{K}_{i}\left(\mathrm{~d}^{-1}\right)$ at $32^{\circ} \mathrm{C}$} & \multicolumn{3}{c}{$\mathrm{K}_{i}\left(\mathrm{~d}^{-1}\right)$ at $39^{\circ} \mathrm{C}$} \\
\hline \multirow{3}{*}{ Mean } & $\mathrm{COD}_{T}$ & $\mathrm{COD}_{\mathrm{F}}$ & Glucose & $\mathrm{COD}_{T}$ & $\mathrm{COD}_{\mathrm{F}}$ & Glucose \\
\cline { 2 - 7 } SD & 0,169 & 0,158 & 0,180 & 0,164 & 0,153 & 0,178 \\
CV (\%) & 0,008 & 0,014 & 0,012 & 0,005 & 0,017 & 0,021 \\
Variance & 4,540 & 9,050 & 6,883 & 3,160 & 11,334 & 11,702 \\
\hline
\end{tabular}

Table7. Coefficient of kinetic decay $\left(K_{i}\right)$ for TS and TVS

\begin{tabular}{ccccc}
\hline & \multicolumn{2}{c}{$\mathrm{K}_{\mathrm{i}}\left(\mathrm{d}^{-1}\right)$ at $32^{\circ} \mathrm{C}$} & \multicolumn{2}{c}{$\mathrm{K}_{\mathrm{i}}\left(\mathrm{d}^{-1}\right)$ at $39^{\circ} \mathrm{C}$} \\
\hline & $\mathrm{TS}$ & $\mathrm{TVS}$ & $\mathrm{TS}$ & $\mathrm{TVS}$ \\
\cline { 2 - 5 } Mean & $0,0508 \mathrm{~b}$ & $0,0770 \mathrm{a}$ & $0,0563 \mathrm{ab}$ & $0,0668 \mathrm{ab}$ \\
SD & 0,009 & 0,003 & 0,014 & 0,006 \\
$\mathrm{CV}(\%)$ & 18,35 & 4,02 & 24,88 & 9,28 \\
Variance & $8,7 \mathrm{E}-05$ & $9,6 \mathrm{E}-06$ & $1,96 \mathrm{E}-04$ & $3,83 \mathrm{E}-05$ \\
\hline *Averages followed by the same letter do not statistically differ within each other $(\mathrm{p}>0,05)$ by & \multicolumn{2}{c}{ Tukey's test. }
\end{tabular}

Methane volume and yields

The absolute volume values of produced methane $\left(\mathrm{V}_{\mathrm{CH} 4}\right)$ were subjected to the ShapiroWilk test at the level of $5 \%$ of significance, ( $p$-value 0,27242 ; F 3,1555) consequently obtaining the normality of the data. The averages of the total volumes produced at $32^{\circ} \mathrm{C}$ and $39^{\circ} \mathrm{C}$ did not present statistic differences when subjected to Tukey's test (F 0,1093; p 0,7574).

Figure 7 presents the volume of the daily produced methane throughout the degradation period, and Figure 8 presents the accumulated methane volume during the biodegradation period. Methane production could be verified in the first 24 hours for both treatments. It was observed that the apex of production occurs in the third day, occurring an abrupt decline in the fourth day, and thence assuming a decline tendency.

Of the produced value at the end of the $8^{\circ}$ day, the volume regarding the endogen decay was discarded, corresponding to $9 \mathrm{~mL}$ for the control bottles incubated at $32^{\circ} \mathrm{C}$, and $10 \mathrm{~mL}$ for the control bottles at $39^{\circ} \mathrm{C}$, resulting in a total volume of effectively produced methane of $49 \mathrm{~mL}$ and $52 \mathrm{~mL}$, respectively. By applying the coefficients of cell production $Y_{\text {acidogenic }}$ of 0,15 and $Y_{\text {methanogenic }} 0,03$ gCOD.g ${ }^{\prime} C O_{\text {removed }}$ (Tchobanoglous et al., 2003) plus adjusting the incubation temperature of the essays, the theoretical volume of methane $\left(\mathrm{V}_{\mathrm{TCH} 4}\right)$ was calculated, corresponding to $0,0632 \mathrm{~L}$ for the experiments at $32^{\circ} \mathrm{C}$, and $0,0653 \mathrm{~L}$ for the experiments at $39^{\circ} \mathrm{C}$ with rumen. Based on the effectively produced volume, the methane yield, in relation to the theoretical methane $\left(\mathrm{R}_{\mathrm{CH}}\right)$ was $77 \%$ and $79 \%$ for the experiments with rumen at $32^{\circ} \mathrm{C}$ and $39^{\circ} \mathrm{C}$, respectively.

In the temperature of $32^{\circ} \mathrm{C}$ the rate of methane production was $249 \mathrm{~mL} \quad \mathrm{CH}_{4} /$ $\mathrm{gCOD}_{\text {applyedb }}$ with removal of $72 \%$ of $\mathrm{COD}_{\mathrm{F}}$. As for the temperature of $39^{\circ} \mathrm{C}$, the rate was $251 \mathrm{~mL}$ 


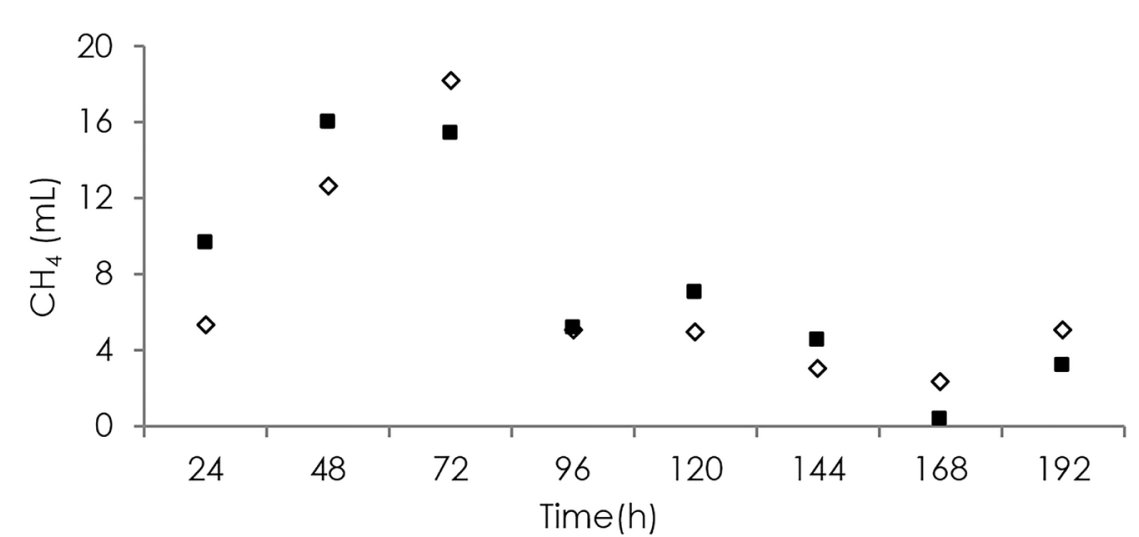

Figure 7. Volume of daily produced methane throughout the degradation period at temperatures $\left({ }^{\circ} \mathrm{C}\right)$ of $32(0)$ and $39(\mathbf{m})$.

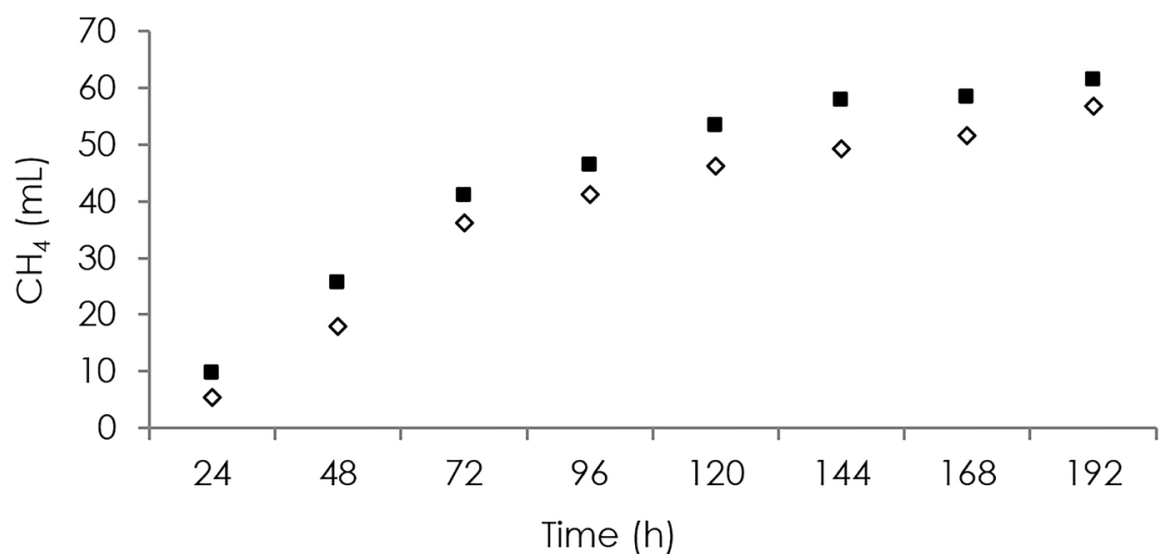

Figure 8. Accumulated methane value for the biodegradation of cassava wastewater with bovine rumen at temperatures $\left({ }^{\circ} \mathrm{C}\right)$ of $\diamond 32$ and $\mathbf{m} 39$.

$\mathrm{CH}_{4} / \mathrm{gCOD}_{\text {applyed }}$ with removal of $71 \%$ of $\mathrm{COD}_{\mathrm{F}}$. Glucose removal was $76 \%$ for both temperatures. Intanoo et al. (2014) obtained values of 164,87 $\mathrm{mL} \mathrm{CH} / \mathrm{g} \mathrm{COD}$ applied and COD removal of $72 \%$, utilizing cassava wastewater in a two-phase UASB reactor, although under thermophilic temperature $\left(55^{\circ} \mathrm{C}\right)$. According to the authors the specific methane production rate is also utilized to indicate the ability of the microbial mass to produce methane from organic compounds per reactor unit or per unit of biomass dry weight. In this work, the specific methane production rates at the temperatures of $32^{\circ} \mathrm{C}$ and $39^{\circ} \mathrm{C}$ were $371 \mathrm{~mL} \mathrm{CH}_{4} / \mathrm{gVSS}$.d and $190 \mathrm{mLCH}_{4} / \mathrm{gVSS}$.d, while Intanoo et al. (2014) obtained the value of $356 \mathrm{~mL} \mathrm{CH} / \mathrm{gVSS}$.d, and Intanoo et al. (2016) obtained a methane yield of $650 \mathrm{~mL} \mathrm{CH} / \mathrm{gVSS}$.d and methane yield of $115 \mathrm{~mL} \mathrm{CH} / / g C O D_{\text {removed. }}$. Intanoo et al. (2014) did also calculate the methane yield in $\mathrm{mL} \mathrm{CH}_{4} / \mathrm{gVSS}$ applied, obtaining the value of $840 \mathrm{~mL} \mathrm{CH} /$ g.TVS applied. In this research the methane yields at the temperatures of $32^{\circ} \mathrm{C}$ and $39^{\circ} \mathrm{C}$ were 0,217 and

\section{$0,226 \mathrm{~mL} \mathrm{CH}_{4} / \mathrm{g}$.VSS of applied biomass.}

Therefore, with no significant differences within the results obtained in the biodegradation utilizing bovine ruminal inoculum at different temperatures, it might be inferred that the biomass activity was not statistically influenced by the evaluated temperatures.

\section{Conclusions}

In the SMA essays, the obtained results demonstrated that the existing microorganisms in the bovine rumen presented a higher potential in converting the organic matter of the acid substrate into methane, when compared to those of the anaerobic sludge and goat rumen. Considering the high specific methanogenic activity of the bovine rumen, this inoculum presents potential for being utilized in substitution to the anaerobic sludge in treatment stations of sanitary swage.

The anaerobic biodegradability of the cassava wastewater utilizing bovine rumen as microbial mass revealed to be efficient. This fact 
was highlighted by the percentages of organic matter reduction in terms of glucose, which variated from $76 \%$ to $80 \%$, and methane yields of $77 \%$ and $7 \%$ at temperatures of $32^{\circ} \mathrm{C}$ and $39^{\circ} \mathrm{C}$, respectively.

It might be finally concluded that the temperature of $32^{\circ} \mathrm{C}$ did not influence the biomass activity of the bovine ruminal inoculum, seen that the kinetic of the cassava wastewater biodegradation did not differ for the evaluated temperatures $\left(32\right.$ and $39^{\circ} \mathrm{C}$ ). Therefore, it might be inferred that this type of inoculum might be alternatively utilized in reactors of anaerobic digestion processes for the treatment of cassava wastewater in the ambient temperature of the semiarid region, being a viable implantation option for the small and average scales of the local industries, with significant socioenvironmental gains.

\section{Acknowledgments}

The authors thank the Fundação de Amparo à Ciência e Tecnologia do Estado de Pernambuco (Facepe), for the financial support APQ-1660-3.07/12, the Embrapa Semiárido, and the Federal University of São Francisco Valley (UNIVASF).

\section{Referências}

American Public Health Association (APHA); American Water Works Association (AWWA), Water Environment Federation (WEF),2012. Standard Methods for the Examination of Water and Wastewater, 22th ed. Washington, DC. 1496 p.

Amorim, S.M., Kato, M. T., Florencio, L., Gavazza, S.P. 2013. Influence of Redox Mediators and Electron Donors on the Anaerobic Removal of Color and Chemical Oxygen Demand from Textile Effluent.Clean 41: 928-933.http://onlinelibrary. wiley.com/doi/10.1002/clen.201200070/abstract

Anyanwu, C.N.,lbeto, C.N., Ezeoha, S.L., Ogbuagu, N.J. 2015.Sustainability of cassava(ManihotesculentaCrantz) as industrial feedstock, energy and food crop inNigeria. Renew. Energy 81: 745-752.https://www. cabdirect.org/cabdirect/abstract/20153330592

Aquino, S.,Chernicharo, C.A.L.,Foresti,E., Santos, M.L.F.,Monteggia, L. O. 2007. Metodologias para determinação da Atividade Metanogênica Específica (AME) em lodos anaeróbios. Revista de Engenharia Sanitária e Ambiental12: 192 201.https://www.abes-dn.org.br/publicacoes/ engenharia/resaonline/v12n02/10006.pdf

Astals, S.,Esteban-Gutiérrez, T., FernándezArévalo, T., Aymerich, E., Gracía-Heras, J. L., MataAlvarez, J. 2013. Anaerobic digestion of seven deferent sewage Sludge: A biodegradability and modelling study. Water Research47: 6033-6043. http://www.sciencedirect.com/science/article/ pii/S0043135413005939

Baba, Y.,Tada, C., Fukuda, Y.,Nakai, Y. 2013. Improvement of methane production from waste paper by pretreatment with rumen fluid. Bioresource Technology 128: 94 - 99.http:// WWW.sciencedirect.com/science/article/pii/ S0960852412014277

Bertolino, S.M.,Carvalho, C.F., Aquino, S.F. 2008. Characterization and biodegradability of wastewater produced in university campus Química - UFV. Engenharia Sanitária e Ambiental 13: 271-277.http: //www.scielo.br/pdf/esa/v13n3/ a05v13n3.pdf

Budiyono, B., Widiasa, I. N., Johari, S.,Sunarso, S. 2009. Influence of Inoculum Content on Performance of Anaerobic Reactors for Treating Cattle Manure using Rumen Fluid Inoculum. International Journal of Engineering and Technology1: 109-116.http://www.enggjournals. com/ijet/docs/IJET09-01-03-04.pdf

Budiyono, B., Kusworo, T. D. 2011. Biogas Production From Cassava Starch Effluent Using Microalgae As Biostabilisator. International Journal of Science and Engineering 2: 4-8.

Chernicharo, C.A. de L. 2007. Princípios do Tratamento Biológico de Águas Residuárias. Reatores anaeróbios. Departamento de Engenharia Sanitária e Ambiental. Belo Horizonte, Brazil. 380p.

Elbeshbishy, E., Hafez, H.,Nakhla, G. 2010. Enhancement of biohydrogenproducing using ultrasonication.International Journal of Hydrogen Energy 35: 6184 - 6193.http://www.sciencedirect. com/journal/international-journal-of-hydrogenenergy/vol/35/issue/12

Field,J. A.,Lettinga, G.,Geurts, M. 1987. The Methanogenic Toxicity and Anaerobic Degradability of Potato Starch Wastewater Phenolic Amino Acids.Biological Wastes 21: 37-54.http://www.sciencedirect.com/journal/ biological-wastes/vol/21/issue/1

Florêncio, L., Pavel, J., Field, J.A., Lettinga, G. 1993. Effect of Cobalt on the Anaerobic Degradation of Methanol.Journal Fermentation and Bioengineering 75: 368-374.http:// WWW.sciencedirect.com/journal/journal-of- 
fermentation-and-bioengineering/vol/75/issue/5

Gerardi, M. H. 2006. Wastewater Bacteria.John Wiley \& Sons, Inc. Hoboken, New Jersey. 255p.

Hook, S.E., Wright, A.D.G., Mcbride, B.W. 2010. Methanogens: Methane Producers of the Rumen and Mitigation Strategies. Archaea 1: 1-11.https:// www.ncbi.nlm.nih.gov/pubmed/21253540

Hu, Z. H,Yu, H. Q.,Yue, Z. B.,Harada, H., Li, Y.Y. 2007. Kinetic analysis of Anaerobic digestion of cattail by rumen microbes in a modified UASB reactor. BiochemistryEngineering Journal 37: 219225. https://www.sciencedirect.com/science/ article/pii/S1369703X07001817

Intanoo, P.,Rangsanvigit, P.,Malakul, P.,Chavadej, S. 2014. Optimization of Separate Hydrogen and Methane Production from Cassava Wastewater using Two-Stage Upflow Anaerobic Sludge Blanket Reactor (UASB) system under Thermophilic Operation. Bioresource Technology173: 256265.http://www.sciencedirect.com/science/ journal/09608524/173

Intanoo, P., Chaimongkol, P., Chavadej, S. 2016. Hydrogen and methane production from cassavawastewater using two-stage Upflow anaerobicsludge blanket reactors (UASB) with an emphasison maximum hydrogen production. International Journal of Hidrogen Energy 41: 6107 6114. http://www.sciencedirect.com/journal/ international-journal-of-hydrogen-energy/vol/41/ issue/14

Kaparaju, P., Serrano, M.,Irini A. I. 2010. Optimization of biogas production from wheat straw stillage in UASB reactor.Applied Energy 87: 3779 - 3783.http://www.sciencedirect.com/ science/article/pii/S0306261910002199

Kuczman, O., Tavares, M. H. F., Gomes, S. D., Guedes, L. P. C., Grisotti, G. 2014. Cassava starch extraction effluent treatment in a one phase tubular horizontal pilot reactor with support medium.EngenhariaAgrícola34: 1270-1282. http://www.scielo.br/scielo.php? script=sci_ arttext\&pid=S0100-69162014000600021 \&lng=en\& $\mathrm{nrm}=\mathrm{iso} \& \operatorname{lng}=e n$

Lucena, R. M., Gavazza, S., Florêncio, L., Kato, M. T., Motais Jr, M. A. 2011. Study of the microbial diversity in a full-scale UASB reactor treating domestic wastewater. World JournalMicrobiologyBiotechnology27: 2893-2902.http://www.scielo.br/scielo. php? script=sci_nlinks\&pid=s 1413 $4152201600020039700018 \& \operatorname{lng}=e n$

Luo, G., Xie, L., Zou, Z., Wanga, W., Zhou, Q. 2010. Exploring optimal conditions forthermophilic fermentative hydrogen production from cassava stillage. International Journal Hydrogen Energy
35: 6161-6169, 2010.

Okudoh, V., Trois, C., Workneh, T., Schmidt, S. 2014. The potential of cassava biomass and applicable technologies for sustainable biogas production in South Africa: a review. RenewableandSustainable Energy Reviews 39: 1035-1052.http://digitalknowledge.cput.ac.za/ xmlui/bitstream/handle/11189/4454/Okudoh_ Vincent_Trois_Cristina_Workneh_Tilahun_ Schmidt_Stefan_AppSci_2014.pdf? sequence=3

Panichnumsin, P., Nopharatana, A.,Ahring, B.,Chaiprasert, P. 2012. Enhanced

Biomethanation in Co-Digestion of Cassava Pulp and Pig Manure Using a Two-PhaseAnaerobic System. Journal of Sustainable Energy e Environment 3: 73-79.

Sánchez, A.S., Silva, Y.L., Kalid, R.A., Cohim, C., Torres E.A. 2017. Waste bio-refineries for the cassava starch industry: New trends and review of alternatives. Renewable and Sustainable Energy Reviews 73: 1265-1275.http://www.sciencedirect. com/science/article/pii/S1364032117302095

Schneiders, D., Silva, J. D.,Till, A., Lapa, K. R., Pinheiro, A. 2013. Atividade metanogênica específica (AME) de lodos industriais provenientes do tratamento biológico aeróbio e anaeróbio. Ambi-Agua8: 135-145.http://www.scielo.br/pdf/ ambiagua/v8n2/14.pdf

Sen, B., Suttar, R. R. 2012. Mesophilic fermentative hydrogen production from sago starch processing wastewater using enriched mixed cultures. International Journal of Hydrogen Energy 37: 15588-15597.

Souto, T.F., Aquino, S.F., Silva, S.Q.,Chernicharo, C.A.L. 2010. Influence of incubation conditions on the specific methanogenic activity test. Biodegradation 21: 411-424.https://www.ncbi. nlm.nih.gov/pubmed/19902364

Sun, L., Shungang, W., Zebin Yu a, Yinghui, W., Shuangfei, W. 2012.Anaerobic biological treatment of high strength cassava starch wastewater in a new type up-flow multistage anaerobic reactor.Bioresource Technology 104: 280-288.http://www.sciencedirect.com/ science/article/pii/S0960852411016816

Teixeira, A.R.,Chernicharo, C.A.L., Aquino, S. F. 2008. Influência da redução do tamanho de partículas na taxa de hidrólise de esgoto bruto doméstico. Engenharia Sanitária eAmbiental 13: 405-415.http://www.scielo. br/scielo.php?script=sci_arttext\&pid=S 1413 $41522008000400009 \&$ Ing $=$ en $\&$ nrm=iso

Tchobanoglous, G., Burton, F.L., Stensel, H.D. 2003. Wastewater engineering: treatment and reuse. Metcalf; Eddy, Inc. 4th. Edition. McGraw- 
Hill. New York, USA. 1771p.

Ubalua, A.O. 2007.Cassava wastes: treatment options and value addition alternatives. African Journal of Biotechnology6: 2065-2073. http://academicjournals.org/journal/AJB/articleabstract/0EC08838826

Ward, A.J., Hobbs, P.J., Holliman, P.J.,Jones, D.L. 2008. Optimisation of the anaerobic digestion of agricultural resources.Bioresource Technology 99: 7928-7940.http://www. sciencedirect.com/science/article/pii/ S0960852408001880?via\%3Dihub

Zhang, M, Xie, L., Yin, Z. Khanal, S.K., Zhou, Q. 2016.Biorefinery approach for cassava-based industrial wastes: Current status and opportunities. Bioresource Technology 215: 50-62.http:// www.sciencedirect.com/science/article/pii/ S0960852416305132 